\title{
Acute cough in Italian children: parents' beliefs, approach to treatment, and the family impact
}

\author{
Roberto W. Dal Negro ${ }^{1 *}$, Alessandro Zanasi ${ }^{2}$, Paola Turco ${ }^{3}$ and Massimiliano Povero ${ }^{4}$
}

\begin{abstract}
Background: Acute cough is the most common symptom among children in primary care, but the impact of cough episodes was never investigated in Italian families.

Methods: A cross-sectional telephone survey was conducted on a representative sample of Italian families, randomly selected from general population; a specific and validated questionnaire was used.

Results: The sample (604 calls) was uniform by geographical distribution, and by children age and gender. Mean cough episode was 3.1/year, they were short lasting (only 4.7\% > 2 weeks). Independent predictors of children cough episodes were parents' active smoking habit and work $(p<0.05)$. The mean nursery/school absenteeism was mostly $<7$ days, but of a 7-15-day duration in near $30 \%$ of cases. The pediatrician was contacted immediately only by $25 \%$ of parents and a second consultation (mostly a lung physician) usually occurred after 2-3 weeks of cough. Meanwhile, home/pharmacist suggested remedies were adopted in $50-70 \%$ of cases. Usual prescriptions were mucolytics (85.8\%), antitussive agents (55.6\%), non-steroideal anti-inflammatory drugs (33.8\%), antibiotics (regularly or episodically $80 \%$ ), and corticosteroids (systemic steroids in less than $50 \%$, but via aerosol in more than $80 \%$ of cases). Moreover, pediatricians claimed to use homeopathic drugs regularly or episodically in almost 50\%. The respondents' willingness to spend out-of-pocket for an "effective remedy" against cough was of $€ 20$ ( $>€ 30$ in 18.4\% of cases).
\end{abstract}

Conclusions: Parents' actions against cough episodes were variable, depending on their beliefs, smoking habit, and occupational status. The parents' perceived efficacy of usual prescriptions is poor, and their willingness to pay out-ofpocket for an "effective remedy" against cough is high. The interest for alternative treatments is not negligible in these circumstances.

Keywords: Acute cough, Acute cough in children, Parents' beliefs, Prescribing attitude, Cough impact

\section{Introduction}

Cough is a physiological mechanism that allows both the protection from the inhalation of airborne irritant materials and the function of clearing secretions from the airways [1]. Nevertheless, cough also represents one of the most common clinical problems, being a non-specific symptom which can be related to a large number of diseases such as bronchial asthma, allergic disorders, post-nasal drip, upper airway infections.

\footnotetext{
* Correspondence: robertodalnegro@gmail.com

${ }^{1}$ National Centre for Respiratory Pharmacoeconomics and

Pharmacoepidemiology, Verona, Italy

Full list of author information is available at the end of the article
}

Cough can be acute or chronic (more than 8 weeks) disorder; acute cough is the most common symptom among children in primary care, and it is mostly due to seasonal respiratory infectious events [2-6].

Even if acute episodes caused by simple cold usually tend progressively to resolve spontaneously within 4-5 days, cough episodes due to influenza and upper airway infections are more severe even in the presence of a mild infection [7-9]. Further to inducing a huge number of general practitioner (GP) or pediatrician visits every year, these episodes represent a relevant cause of school absenteeism, which in turn can also affect parents' working activities substantially [10]. For these reasons, high rates of vaccination coverage are encouraged and promoted

(c) The Author(s). 2019 Open Access This article is distributed under the terms of the Creative Commons Attribution 4.0 International License (http://creativecommons.org/licenses/by/4.0/), which permits unrestricted use, distribution, and 
because these actions can minimize both the morbidity and the societal impact of airway tract infections, together to the impact of related cough episodes [11].

The epidemiology of cough was only episodically investigated in Italian children [12], but the true impact of cough episodes on their families was never assessed in Italian general population to our knowledge.

Aim of the study was to investigate the clinical characteristics of cough episodes in children, parents' beliefs, and pediatrician's attitude to therapeutic intervention.

\section{Material and methods}

The study was planned by National Centre for Respiratory Pharmacoeconomics and Pharmacoepidemiology (CESFAR), the Italian Association for Study of Cough (AIST), and AdRes. The study (conducted between March $\left.5^{\text {th }}-21^{\text {st }}, 2017\right)$ was approved by the CESFAR Ethical Committee on October $26^{\text {th }}, 2016$ (n.A/002/16).

A cross-sectional telephone survey was carried out on a representative sample of Italian families with children, randomly selected from general population. The tool for investigation was a specific, validated, anonymous questionnaire (Additional file 1). All interviews to children's parents were conducted according to the Computer Assisted Telephone Interview (CATI) methodology [13] by expert, professional interviewers. The interviewer was provided with one "work station" consisting of a personal computer connected to a central processing unit. The central unit was also equipped with a specific software for the random choice of individuals (such as, the telephone numbers) to contact. The sampling strategy adopted in the present survey was the random selection of an adequate number of subjects. All interviews were always preceded by a short explanation of the aim of the survey, and had a mean duration of ten minutes.

A minimum number of 600 respondent families with children was previously calculated for achieving the representativity of the sample in terms children's age, gender, and geographical distribution (3\% mean effect size; $5 \%$ significance level, and $80 \%$ statistical power) [14].

Only interviews obtained after obtaining the respondent's informed consent to the interview and to the possible use of information for scientific purposes were considered.

\section{Statistical analysis}

All collected data were summarized using percentage of responses, or mean and standard deviation. For continuous outcomes not normally distributed, median and interquartile range were also reported. As concerning categorical answers, the mean value of each category was considered in order to compute the weighted mean.

Normality was tested using Shapiro-test while differences in categorical outcomes were assessed using
Chi-squared test; a $p$ - lower than 0.05 was chosen to asses statistical significance. All analyses were performed using computer software R 3.1.2 [15].

\section{Results}

Total calls were 1,716 , and only 79 contacts $(4.1 \%)$ refused immediately their consensus. A total of 604 questionnaires were usable, and then collected and analyzed, by a redemption rate of $35.2 \%$.

Respondent parents had an average age of around 40 years (IQR: 36-44) and their children of about 7 years (IQR: 4-9). The distribution of responders proved absolutely uniform in geographical terms and also by their child/children's age and gender. In the majority of cases, mothers (80\%) filled questionnaires; furthermore, at least one of the two parents was an active smoker in almost $60 \%$ of respondent families (Table 1 ).

The joint distribution by parents' job is reported in Table 2: clerk-clerk, clerk-laborer, clerk-housewife, laborer-housewife, and laborer-laborer were the most frequent job combinations within the parents' sample.

In the last 12 months, more than $90 \%$ of children experienced cough episode: more than half of these children had at least 3 cough episodes and $13.4 \%$ more than five episodes over the same period (Table 3 ). The mean annual rate results in 3.15 episodes per year. Usually, these episodes had a short duration, and cough lasted for more than 2 weeks only in $5.4 \%$ of cases.

While children suffering from 1 to 2 cough episodes/ year were much more frequent in smoke-free families (Table 3), those suffering from 3 to 5 episodes/year were significantly more frequent in families where at least one parent was an active smoker $(p<0.046)$. Also the 7 15-day duration of cough episodes was more frequent in families with active smokers when compared to that of the smoke-free ones (such as: a prevalence of $61.7 \%$ vs $50.8 \%$, respectively). Unfortunately, even if pretty clear,

Table 1 General characteristics of children and families

\begin{tabular}{lll}
\hline & Mean (SD) & Median (IQR) \\
\hline Age of child & $6.92(3.28)$ & $6(4-9)$ \\
Age of respondent parent & $40.39(6.19)$ & $41(36-44)$ \\
Gender of child (\% male) & $52.98 \%$ & \\
Gender of respondent parent (\% female) & $80.46 \%$ \\
Smokers in the family (\% at least un parent) & $57.57 \%$ \\
Geographic area & \\
North-West & $25.17 \%$ \\
North-Est & $25.17 \%$ \\
Center & $21.52 \%$ \\
South and Islands & $28.15 \%$ \\
\hline
\end{tabular}

$S D$ standard deviation, $I Q R$ interquartile range 
Table 2 Joint distribution of both parents by their occupation

\begin{tabular}{|c|c|c|c|c|c|c|c|c|c|c|c|}
\hline $\begin{array}{l}\text { Parent } 2 \\
\text { Parent } 1\end{array}$ & Entrepreneur & Manager & Clerk & Laborer & Craftsman & Self employed & Merchant & $\begin{array}{l}\text { Independent } \\
\text { contractor }\end{array}$ & Retired & Housewife & Unemployed \\
\hline Entrepreneur & $0.2 \%$ & & & & & & & & & & \\
\hline Manager & $0.2 \%$ & $0.7 \%$ & & & & & & & & & \\
\hline Clerk & $1.0 \%$ & $2.0 \%$ & $21.0 \%$ & & & & & & & & \\
\hline Laborer & $0.3 \%$ & $0.7 \%$ & $13.4 \%$ & $4.9 \%$ & & & & & & & \\
\hline Craftsman & $0.3 \%$ & $0.0 \%$ & $0.7 \%$ & $0.7 \%$ & $0.2 \%$ & & & & & & \\
\hline Self employed & $0.7 \%$ & $0.3 \%$ & $7.9 \%$ & $3.4 \%$ & $0.5 \%$ & $1.3 \%$ & & & & & \\
\hline Merchant & $0.3 \%$ & $0.0 \%$ & $1.2 \%$ & $0.5 \%$ & $0.0 \%$ & $0.7 \%$ & $0.0 \%$ & & & & \\
\hline $\begin{array}{l}\text { Independent } \\
\text { contractor }\end{array}$ & $0.3 \%$ & $0.2 \%$ & $1.5 \%$ & $0.5 \%$ & $0.2 \%$ & $1.2 \%$ & $0.3 \%$ & $0.3 \%$ & & & \\
\hline $\begin{array}{l}\text { Precarious } \\
\text { worker / student }\end{array}$ & $0.0 \%$ & $0.0 \%$ & $0.3 \%$ & $0.0 \%$ & $0.0 \%$ & $0.2 \%$ & $0.0 \%$ & $0.0 \%$ & $0.0 \%$ & & \\
\hline Housewife & $0.3 \%$ & $0.8 \%$ & $8.1 \%$ & $6.7 \%$ & $0.3 \%$ & $3.4 \%$ & $0.2 \%$ & $0.5 \%$ & $0.2 \%$ & $0.8 \%$ & \\
\hline Unemployed & $0.3 \%$ & $0.2 \%$ & $4.2 \%$ & $2.9 \%$ & $0.2 \%$ & $1.7 \%$ & $0.2 \%$ & $0.2 \%$ & $0.0 \%$ & $0.3 \%$ & $0.3 \%$ \\
\hline
\end{tabular}

this tendency did not reach the minimum level of statistical significance.

The geographical distribution of families did not affect neither the rate nor the duration of cough episodes (Table 3). On the contrary, the rate of cough episodes proved affected by the parents' occupational status; it was significantly higher in the families where both parents were active workers, and significantly lower in those families where at least one parent was at home for the great part of the day (Fig. 1).

In the majority of cases cough was reported as initially dry, and accompanied by secretions of variable extent in the following days, while dry cough only and cough immediately productive were reported in a small proportion of case. In the large majority of cases cough was lasting over the day, followed by over day and night (Table 4).

Cough episodes affected both children's sleep and school activities at different extent in the large majority of cases (Table 5). Even if the mean nursery/school absenteeism was generally shorter than 7 days, in about $30 \%$ of cases duration is 7-15-day. One of the two parents $(69.6 \%)$, or grandparents (29.1\%), usually took care of the child/children, resulting the baby-sitter or other caregiver's role quite negligible in the present study.

When a cough episode occurred, the medical referral was usually rapid: $26 \%$ of parents tended to contact the pediatrician immediately, while in the majority of cases the doctor was called within the first 7 days of child's cough. A second referral (of a lung physician in the

Table 3 Rate and duration of cough episodes

\begin{tabular}{|c|c|c|c|c|c|c|c|c|}
\hline & \multirow[t]{2}{*}{ Total population } & \multicolumn{3}{|c|}{ Parents' smoking status } & \multicolumn{4}{|c|}{ Geographical distribution } \\
\hline & & Both smoking & One smoking & None smokers & North-West & North-Est & Center & South and Islands \\
\hline \% child with cough episodes & $91.06 \%$ & $95.92 \%$ & $90.81 \%$ & $90.56 \%$ & $89.47 \%$ & $94.74 \%$ & $91.54 \%$ & $88.82 \%$ \\
\hline $\begin{array}{l}\text { Number of episodes } \\
\text { (mean episodes per year) }\end{array}$ & 3.15 & 3.34 & 3.14 & 3.13 & 3.03 & 3.25 & 3.13 & 3.17 \\
\hline 1-2 episodes & $44.91 \%$ & $38.30 \%$ & $42.70 \%$ & $46.96 \%$ & $47.79 \%$ & $42.36 \%$ & $45.38 \%$ & $44.37 \%$ \\
\hline 3-5 episodes & $41.64 \%$ & $46.81 \%$ & $47.03 \%$ & $37.70 \%$ & $41.18 \%$ & $42.36 \%$ & $41.18 \%$ & $41.72 \%$ \\
\hline$>5$ episodes $^{a}$ & $13.45 \%$ & $14.89 \%$ & $10.27 \%$ & $15.34 \%$ & $11.03 \%$ & $15.28 \%$ & $13.45 \%$ & $13.91 \%$ \\
\hline $\begin{array}{l}\text { Length of episodes } \\
\text { (mean days per episode) }\end{array}$ & 8.42 & 9.06 & 8.50 & 8.27 & 9.15 & 8.22 & 8.36 & 8.02 \\
\hline$<7$ days & $40.91 \%$ & $31.91 \%$ & $39.46 \%$ & $43.45 \%$ & $35.29 \%$ & $40.28 \%$ & $44.54 \%$ & $43.71 \%$ \\
\hline $7-15$ days & $53.64 \%$ & $61.70 \%$ & $55.68 \%$ & $50.80 \%$ & $56.62 \%$ & $56.25 \%$ & $49.58 \%$ & $51.66 \%$ \\
\hline 16-30 days & $4.73 \%$ & $6.38 \%$ & $3.78 \%$ & $5.11 \%$ & $7.35 \%$ & $2.78 \%$ & $4.20 \%$ & $4.64 \%$ \\
\hline$>30$ days & $0.73 \%$ & $0.00 \%$ & $1.08 \%$ & $0.64 \%$ & $0.74 \%$ & $0.69 \%$ & $1.68 \%$ & $0.00 \%$ \\
\hline
\end{tabular}

${ }^{a}$ Maximum number of episodes per year is 7 . This limit was estimated fitting a Poisson distribution on the frequencies recorded in the questionnaires 


\section{Number of episodes (mean)}

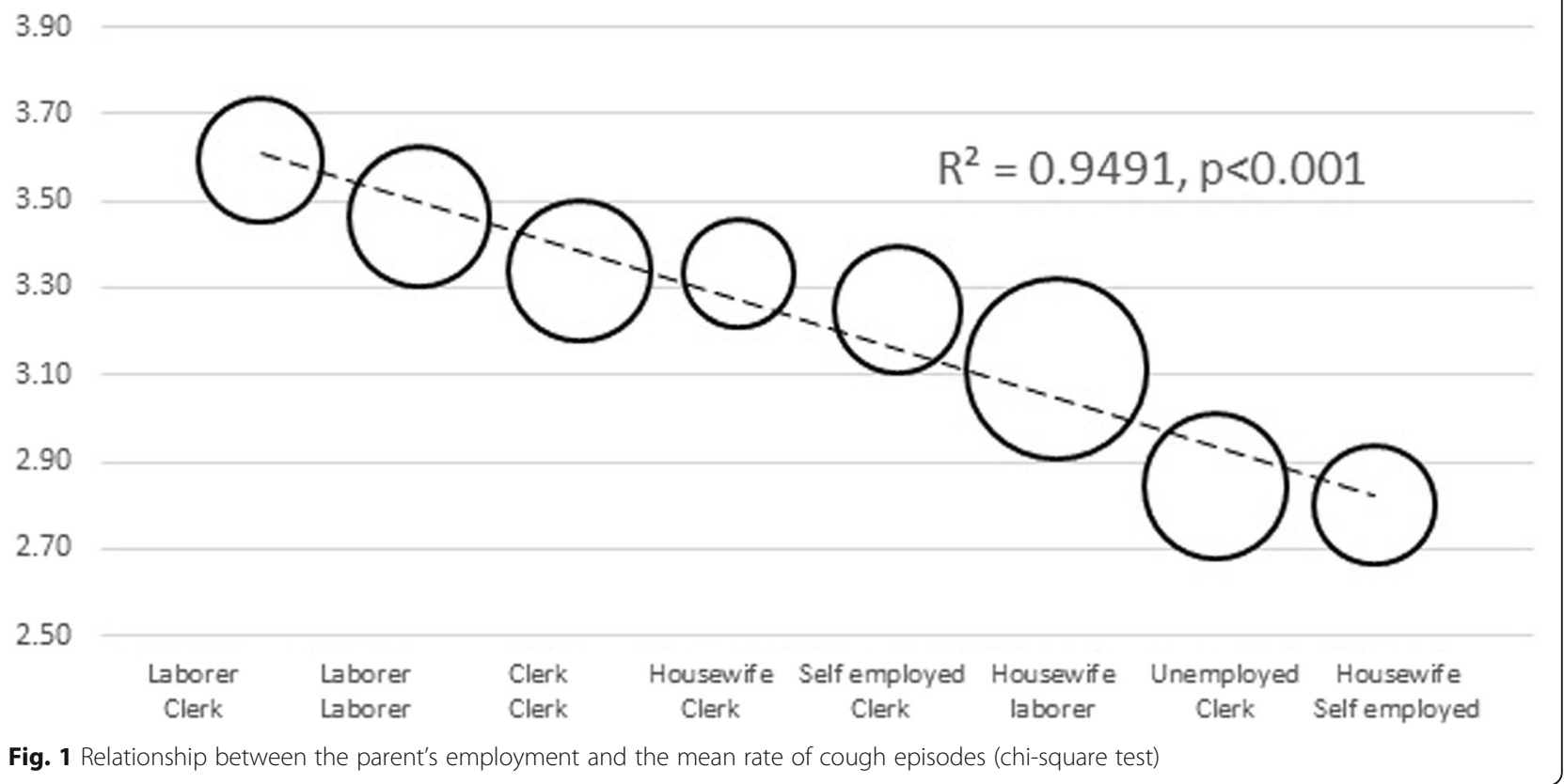

majority of cases) usually occurred when cough did not disappear or attenuate significantly within 2-3 weeks (Table 6). Meanwhile, home remedies or symptomatic remedies suggested by the pharmacist were usually adopted in 71.5 and $51.2 \%$ of cases, respectively.

The pediatrician's therapeutic approach to cough is summarized in Table 7. In general, the aerosol therapy appeared the preferred route for drug administration in these circumstances. Systemic antitussive and non-steroideal anti-inflammatory drugs were also frequently prescribed as first-line options (such as, in more than 25\% of cases). Antibiotics were not used in near $15 \%$ of cases only, but they were prescribed regularly or episodically in near $80 \%$ of cases. Systemic corticosteroids were reported as episodically prescribed in near $50 \%$ of episodes, but usually prescribed in $5 \%$ of cases. However,

Table 4 Type and occurrence of cough

\begin{tabular}{ll}
\hline Type & \\
Dry & $14.55 \%$ \\
Initially dry followed by secretions & $74.18 \%$ \\
Initially with secretions & $10.55 \%$ \\
Don't know / prefer not to answer & $0.73 \%$ \\
Occurrence & \\
Day only & $11.82 \%$ \\
Day and night & $82.36 \%$ \\
Night only & $5.27 \%$ \\
Exertional only & $0.55 \%$ \\
\hline
\end{tabular}

mucolytics (85.8\%), cough suppressant (55.6\%), and non-steroideal anti-inflammatory drugs (33.8\%) were the most preferred therapeutic options.

The general respondents' concern was more or less equally distributed against corticosteroids and antibiotics, even if their highest concern was against corticosteroids rather than antibiotics $(20.6 \%$ vs $8.1 \%$, respectively) (Table 7). In general, these drugs were perceived as effective by $48.7 \%$, and highly effective by $4.8 \%$ of respondents, even if in $36.8 \%$ of cases the effectiveness was reported as poor, and in $7.1 \%$ they were defined as ineffective.

The respondents' willingness to spend out-of-pocket for an "effective remedy" against their children's cough ranged $€ 14.0-25.9$, by an average of $€ 20.0$. Even if their willingness to spend was of $€ 10-20$ in more than 53\% of cases, it ranged $€ 20-30$ in $10.7 \%$, and was higher than $€ 30$ in $18.4 \%$ of cases, respectively (Table 8 ).

Finally, while $51.7 \%$ of pediatricians never prescribed homeopathic drugs against cough (at least according to parents' interview), $24.7 \%$ of them prescribed these drugs regularly, and $23.7 \%$ episodically (Table 9). Homeopathic anti-cough drugs were defined effective by $34.8 \%$, and not or poor effective by $53.6 \%$ of respondents, respectively. When the reasons of their beliefs were specifically requested, almost $65 \%$ of pro respondents claimed that homeopathy would be regarded as a safe and alternative therapeutic option in these cases. On the contrary, more than $35 \%$ of on respondents were adamant in denying any efficacy to these drugs. 
Table 5 Effect of cough episodes on both sleep and school activities

\begin{tabular}{|c|c|c|c|c|c|c|}
\hline \multirow[b]{2}{*}{ Never } & \multirow{2}{*}{$\begin{array}{l}\text { Sleep } \\
3.31 \% \\
\end{array}$} & \multirow{2}{*}{$\begin{array}{l}\text { School activities } \\
12.91 \%\end{array}$} & \multicolumn{2}{|c|}{ Nursery/school absenteeism } & \multicolumn{2}{|l|}{ Home caring } \\
\hline & & & $<7$ days & $62.73 \%$ & Parent(s) & $69.60 \%$ \\
\hline Sometimes & $63.91 \%$ & $59.27 \%$ & $7-15$ days & $28.36 \%$ & Grandparents & $29.12 \%$ \\
\hline Often & $25.83 \%$ & $22.85 \%$ & 16-30 days & $3.64 \%$ & Other ${ }^{a}$ & $1.28 \%$ \\
\hline Always & $6.95 \%$ & $4.47 \%$ & $>30$ days & $4.55 \%$ & & \\
\hline Don't know/prefer not to answer & - & $0.50 \%$ & No kindergarten/school & $0.73 \%$ & & \\
\hline
\end{tabular}

aincluding baby-sitter

\section{Discussion}

In concordance with consolidated literature $[2-6,8,9]$, the incidence of cough episodes reported in present survey proved very high indeed, as more than $90 \%$ of Italian children suffered from these events over the year, though at different rates, severity, and duration.

These events (mostly due to upper respiratory tract infections of viral origin) cause significant, even though transient, limitations in the usual activities and in the quality of life of sick children, but can also frequently cause the involvement of other family members. It is then presumable that this sort of epidemic spreading within the family would have further triggered a not negligible limitation also in parents' daily life, particularly when parents are the only home care-givers of their child/children.

Furthermore, it should be considered that cough episodes occur much more frequently in a sizable cluster of children than in others, and the overall duration of all the annual events can lead to a relevant socio-economic impact in these cases.

The parents' smoking habit plays a quite relevant role, as this negative attitude proved strictly related to the annual rate of children's cough episodes in the present study, independently of the geographical region where the family lives. Even if only acute cough was investigated in the present study, data further support, even if indirectly, the dangerous effect of the indoor second-hand smoke on children [16] and strongly stress the heavy responsibility of smoking parents versus their own children.

Moreover, the strict relationship between the status of parents' occupation and the rate of annual cough

Table 6 Time for a pediatrician and of another specialist consultation

\begin{tabular}{lll}
\hline & Pediatrician & Another specialist \\
\hline Immediately & $25.50 \%$ & $2.32 \%$ \\
$<7$ days & $60.60 \%$ & $25.99 \%$ \\
$7-15$ days & $8.77 \%$ & $30.63 \%$ \\
16-30 days & $2.32 \%$ & $19.04 \%$ \\
$>30$ days & $0.83 \%$ & $9.60 \%$ \\
Don't know / prefer not to answer & $1.99 \%$ & $12.42 \%$ \\
\hline
\end{tabular}

episodes came out from the present study as a quite novel piece of evidence. Actually, data seem to suggest that when at least one parent is usually at home for many hours/day, the impact of cough episodes is significantly lower. Several factors can be suggested for explaining this phenomenon: in particular, a reduced infectious risk and a more effective home children caring can be presumed in these cases. Conversely, the child caring provided by other care-givers appears less effective, also in terms of cough episode duration. In the particular case of grand-parents' caring, it also plausible that their emotional concern may lead to the magnified description of cough events.

In terms of children's home management, two main factors are presumed to affect the scenario in these circumstances: first, the parents' desire to define and resolve the cause of symptoms of their child/children as soon as possible, and, secondly, the parents' need to safeguard their job and their economic position. As suggested in previous papers $[17,18]$, both these conditions contributes to stimulate a quick doctor's intervention.

Actually, even if domestic remedies and those suggested by the pharmacist are generally immediately preferred, the medical referral is usually searched with a very short delay since the cough onset. Criteria which lead to the doctor consultation are of several origins, and not fully understood yet. The persistency of intense cough for $24 \mathrm{~h}$, together with a persisting fever, and the occurrence of other respiratory signs (namely, dyspnea and/or wheezing) are presumed to represent the major determinants [19]. However, other factors can further differently contribute to the parents' concern and to the decision in favor of a medical intervention, such as: the anxiety of one or of both parents; their insufficient coping skills (particularly if they are young and at their first experience); the role of other family components (mainly grand-parents) who press for a rapid diagnosis and a rapid therapeutic intervention; the disruption of their daily organization; the fear of negative effects on their working life [20,21].

As expected, the pediatrician is usually the first doctor to be consulted, followed by the Lung Physician, who is preferred in particular clinical conditions, such as when cough is long-lasting or is complicated by other 
Table 7 Pediatrician's most prescribed drugs and parents' concerned toward prescriptions

\begin{tabular}{|c|c|c|c|c|}
\hline & Antibiotics & Corticosteroids & Antitussive Anti-inflammatory & Aerosol \\
\hline \multicolumn{5}{|l|}{ Prescribed by pediatrician } \\
\hline Always & $5.30 \%$ & $4.97 \%$ & $26.66 \%$ & $33.61 \%$ \\
\hline Sometimes & $78.15 \%$ & $43.38 \%$ & $64.07 \%$ & $49.34 \%$ \\
\hline Never & $15.40 \%$ & $49.67 \%$ & $7.95 \%$ & $17.05 \%$ \\
\hline $\begin{array}{l}\text { Don't know / prefer not } \\
\text { to answer }\end{array}$ & $1.16 \%$ & $1.99 \%$ & $1.32 \%$ & - \\
\hline \multicolumn{5}{|l|}{ Parents' concerned } \\
\hline No & $8.33 \%$ & $5.48 \%$ & & \\
\hline A little & $36.51 \%$ & $26.37 \%$ & & \\
\hline Very & $47.02 \%$ & $46.23 \%$ & & \\
\hline Highly & $8.13 \%$ & $20.55 \%$ & & \\
\hline $\begin{array}{l}\text { Don't know / prefer } \\
\text { not to answer }\end{array}$ & - & $1.37 \%$ & & \\
\hline
\end{tabular}

respiratory signs (namely, wheezing; at rest or exertional dyspnea, high fever, etc.).

The vast majority of pediatricians' home prescriptions consists in antibiotics, corticosteroid (mostly via the inhalation route), mucolytics, antitussive drugs, and non-steroideal anti-inflammatory agents. As in previous studies [22, 23], antibiotics still result over-prescribed and their use is presumed as largely inappropriate also in the present survey. Actually, the reported characteristics of cough (initially mainly dry for a few days) would have suggested the occurrence of an upper airway viral infection in the majority of cases. Consequently, the immediate prescription of antibiotics and/or oral steroids should then have been regarded as an inappropriate first-line therapeutic choice. Nevertheless, data from the present survey further confirm how persisting is the attitude of antibiotic prescribing in primary care, independently of the subjects' age and of a precise etiology of cough [24, 25], and regardless of the high parental concern against antibiotics and corticosteroids.

From this point of view, it should be emphasized that also the National Guidelines for the management of influenza-like syndrome in adults and children do not recommend the use of antibiotics in non-complicated conditions, unless the clinical picture is evident for proven bacterial co-infections [26]. Moreover, a recent

Table 8 Willingness to pay for an effective cough product

\begin{tabular}{ll}
\hline Mean (range) & $€ 19.95(14.04-25.86)$ \\
\hline Nothing & $0.33 \%$ \\
$<10$ euros & $10.43 \%$ \\
$10-20$ euros & $53.64 \%$ \\
$20-30$ euros & $10.76 \%$ \\
$>30$ euros & $18.38 \%$ \\
Don't know / prefer not to answer & $6.46 \%$ \\
\hline
\end{tabular}

Cochrane review investigated the benefits and the risk of antibiotics for cough due to acute bronchitis, being cough one of the most common disorders to face in primary care. Results confirmed that there is limited evidence in favor of the antibiotics use in these circumstances. However, the magnitude of benefits achievable should be further carefully compared to the potential side effects and to the risk of increasing induced-resistance to respiratory pathogens [27].

As reported above, the aerosol route for drug administration was largely preferred by pediatricians, even if there still is insufficient evidence for recommending inhaled steroids in cough due to upper respiratory tract infections [28], and several studies recommended the reduction of "over-the-counter" anti-cough medicines in children due to their several side-effects, particularly during the first years of life [29, 30].

In general, the concept suggested in some previous papers that "the cure can be worse than the cough" in several cases of primary care management [31-33] is then plausible and worth to be shared in the majority of cases.

Table 9 Parents' beliefs on homeopathic drugs

\begin{tabular}{lll}
\hline & Yes & No \\
\hline Homeopathy as an alternative & $64.72 \%$ & $35.28 \%$ \\
Why yes? & & \\
$\quad$ Safe & $57.88 \%$ & \\
Effective & $26.97 \%$ & \\
$\quad$ Alternative & $15.15 \%$ & \\
Why not? & & $84.02 \%$ \\
Non effective & & $11.24 \%$ \\
Less effective & & $4.73 \%$ \\
Too much expensive & & \\
\hline
\end{tabular}


Actually, the care-givers' perceived efficacy of usually prescribed drugs is generally poor during cough episodes. This evidence is also confirmed by the high parents' willingness to pay out-of-pocket for an "effective remedy" against their child's cough. A further indirect confirmation of this hypothesis comes from the positive attitude of respondents versus alternative therapeutic interventions against cough. At present, this complementary approach results in increasing progression in our as in other countries [34]. However, this approach is still generally "belief-based", and further controlled scientific information is needed for pediatricians and families, particularly in terms of potential side effects and risk.

The present study has some limitations: it was conducted according to a cross-sectional, retrospective design, not aimed to the precise definition of cough etiology and to the assessment of prospectic outcomes. Information were collected by a questionnaire also usable by care-givers different from the two parents. Furthermore, information on therapeutic prescriptions were derived from parents or care-givers, and not directly from pediatricians or GPs.

A point of strength is that the study was conducted on a representative sample of Italian families evenly distributed across the national regions, and the corresponding redemption was pretty good.

\section{Conclusions}

Cough is very frequent in children. Cough episodes recognize variable etiology, rates, and duration over the year. Both the rate and the duration of cough episodes can cause a substantial impact on families, depending of their occupational status and smoking habit. The parents' behavior when facing their children's cough episodes is variable and depending of several factors, still not explored exhaustively. Their job status, smoking habit and family organization affect decisions. Usual home prescriptions are largely inappropriate and frequently merely related to environmental suggestions. The parents' perceived efficacy of usual therapeutic options is frequently poor and, conversely, high is the willingness to pay out-of-pocket for an effective remedy against cough. The interest for alternative treatments is also not negligible in these circumstances.

\section{Additional file}

Additional file 1: Cough Questionnaire. (DOCX $118 \mathrm{~kb}$ )
Availability of data and materials

The datasets generated and/or analysed during the current study are not publicly available due to individual privacy but are available from the corresponding author on reasonable request.

\section{Authors' contributions}

RWD planned the study and wrote the manuscript. MP performed the analytic calculations and wrote the manuscript. Both AZ and PT authors provided critical feedback and contributed to the final version of the manuscript. All authors read and approved the final manuscript.

\section{Ethics approval and consent to participate}

The study was approved by the CESFAR Ethical Committee on October $26^{\text {th }}$, 2016 (n. A/002/16).; all participants have given their consent.

Consent for publication

Not applicable.

\section{Competing interests}

Roberto Dal Negro is an Associate Editor of Multidisciplinary Respiratory Medicine. Alessandro Zanasi participated as speaker at Boiron's internal meeting in the past. Paola Turco and Massimiliano Povero declare no conflict of interests.

\section{Publisher's Note}

Springer Nature remains neutral with regard to jurisdictional claims in published maps and institutional affiliations.

\section{Author details}

${ }^{1}$ National Centre for Respiratory Pharmacoeconomics and Pharmacoepidemiology, Verona, Italy. ${ }^{2}$ Italian Association for Cough Study (AIST), Bologna, Italy. ${ }^{3}$ Research \& Clinical Governance, Verona, Italy. ${ }^{4}$ AdRes Health Economics and Outcome Research, Torino, Italy.

Received: 24 October 2018 Accepted: 18 March 2019

Published online: 04 April 2019

References

1. Chung KF, Lalloo UG. Diagnosis and management of chronic persistent dry cough. Postgrad Med J. 1996;72:594-8.

2. Monto AS, Cavallaro JJ. The Tecumseh study of respiratory illness. II. Patterns of occurrence of infection with respiratory pathogens. 1965-1969. Am J Epidemiol. 1971;94:280-9.

3. McCormick A, Fleming D, Carlton J. Morbidity statistics from general practice. Fourth national study 1991-1992. London: HMSO; 2006.

4. Drescher BJ, Chang AB, Phillips N, Acworth J, Marchant J, Sloots TP, et al. The development of chronic cough in children following presentation to a tertiary paediatric emergency department with acute respiratory illness: study protocol for a prospective cohort study. BMC Pediatr. 2013;13:125.

5. European Centre for Disease Prevention and Control, Questions and answers on seasonal influenza. https://ecdc.europa.eu/en/seasonal-influenza/facts/ questions-and-answers-seasonal-influenza Accessed June 2018.

6. Liu WK, Liu Q, Chen DH, Liang HX, Chen XK, Huang WB, et al. Epidemiology and clinical presentation of the four human parainfluenza virus types. BMC Infect Dis. 2013;13:28. https://doi.org/10.1186/1471-2334-13-28.

7. Allen LV. Colds and cough. Int J Pharm Compd. 2012:16:480-3.

8. Fu Y, Pan L, Sun Q, Zhu W, Zhu L, Ye C, et al. The clinical and etiological characteristics of influenza-like illness (ILI) in outpatients in Shanghai, China, 2011-2013. PLoS One. 2015;10:e119513.

9. Giannattasio A, Lo Vecchio A, Napolitano C, Di Florio L, Guarino A. A prospectic study on ambulatory care provided by primary care pediatricians during influenza season. Ital J Pediatr. 2014;40:38.

10. Hollinghurst S, Gorst C, Fahey T, Hay AD. Measuring the financial burden of acute cough in pre-school children: a cost of illness study. BMC Fam Pract. 2008;9:10. https://doi.org/10.1186/1471-2296-9-10.

11. Piedra PA. Societal and economic consequences of influenza. Manag Care. 2008;17(suppl. 10):8-14.

12. De Blasio F, Dicpinigaitis PV, Rubin BK, De Danieli G, Lanata L, Zanasi A. An observational study on cough in children: epidemiology, impact on quality of sleep and treatment outcome. Cough. 2012;8:1. 
13. Kraut R, Brynin M, Kiesler S. Computers, phones, and the internet: domesticating information technology. Oxford: Oxford University Press; 2006

14. Dal Negro RW, Turco P, Povero M. Cost of acute cough in Italian children. ClinicoEconomics and Outcomes Research. 2018;10:529-37.

15. R Core Team (2013) R: a language and environment for statistical computing R Foundation for statistical computing, Vienna, Austria https:// wwwr-projectorg/ Accessed June 2018.

16. Oberg M, Jaakkola MA, Woodward A, Peruga A, Prüss-Ustün A. Worldwide burden of disease from exposure to second-hand smoke; a retrospective analysis of data from 192 countries. Lancet. 2011;377:139-46.

17. Janike DM, Finney JW, Riley AW. Children's health care use: a prospective investigation of factors related to care-seeking. Med Care. 2001;39:990-1001.

18. Little P, Somerville J, Williamson I, Warner G, Moor M, Wiles R, et al. Family influence in a cross-sectional survey of higher child attendance. Brit J Gen Pract. 2001;51:977-84.

19. Ertmann RK, Siersma V, Reventlow S, Söderström M. Infants symptoms of illness assessed by parents: impact and implications. Scand J Prim Health Care. 2011;29:67-74

20. Bruijnzeels MA, Foets M, van der Wouden JC, van der Wouden WJ, Prins A. Everyday symptoms in childhood: occurrence and general practitioner consultation rate. Brit J Gen Pract. 1998;48:880-4.

21. Ertmann RK, Soderstrom M, Reventlov S. Parent's motivation for seeing a physician. Scand J Prim Health Care. 2005;23:154-8.

22. Eckel N, Sarganas G, Wolf IK, Knopf H. Pharmacoepidemiology of common colds and upper respiratory tract infections in children and adolescent in Germany. BMC Pharmacol Toxicol. 2014;15:44.

23. Rezal RS, Hassali MA, Alrasheedy AA, Saleem F, Yusof FA, Kamal M, et al. Prescribing pattern for upper respiratory tract infections: a prescriptionreview of primary care practice in Kedha, Malaysia. Expert Rev Anti Infect Ther. 2014;5(13):1547-56.

24. Run Siguroarddottir N, Nielsen AB, Munck A, Bjerrum L. Appropriateness of antibiotic prescribing for upper respiratory tract infections in general practice: comparison between Denmark and Iceland. Scand J Prim Health Care. 2015;33:269-74.

25. Tyrstrup M, van der Velden A, Engstrom S, Goderis G, Molstad S, Verheij T, et al. Antibiotic prescribing in relation to diagnoses and consultation rates in Belgium, the Netherlands and Sweden: use of European quality indicators. Scand J Prim Health Care. 2017;35:10-18.

26. Morciano C, Vitale A, De Masi S, Sagliocca L, Sampaolo L, Lacorte E, et al. Italian evidence-based guidelines for the management of influenza-like syndrome in adults and children. Ann Ist Super Sanità. 2009;45:185-92.

27. Smith SM, Fahey T, Smucny J, Becker LA. Antibiotics for acute bronchitis. Cochrane Database Syst Rev. 2017 Jun 19;6:CD000245.

28. El-Gohary M, Hay AD, Coventry P, Moore M, Stuart B, Little P. Corticosteroids for acute and subacute cough following respiratory tract infections. Fam Pract. 2013;30:492-500.

29. Hanoch Y, Gummerun M, Miron-Shayz T, Himmelstein M. Parents' decision following the Food and Drug Administration recommendation: the case of over-the-counter cough and cold medications. Child Care Health Dev. 2010; 36:795-804.

30. Alauzet F, Banide MC, Pailhes C, Blanc S, Montaudié I, Piccini-Bailly C. Acute cough in infants: impact on national guidelines on medical practices in a French department. Arch Pediatr. 2014;21:461-8.

31. Spencer CA. Is the cure worse than the cough ? Hosp Top. 1982;60:7.

32. Hueston WJ. Antibiotics: neither cost effective nor "cough" effective. J Fam Pract. 1997;44:261-5.

33. Wallis KA. Non medicine is sometimes the best medicine. BMJ Case Rep. 2015;2015. https://doi.org/10.1136/bcr-2014-207152.

34. Tuncel T, Sen V, Kelekci S, Karabel M, Sahin C, Uluca U, et al. Use of complementary and alternative medicine in children who have no chronic disease. Turk Pediatric Ars. 2014:49:148-53.

\section{Ready to submit your research? Choose BMC and benefit from:}

- fast, convenient online submission

- thorough peer review by experienced researchers in your field

- rapid publication on acceptance

- support for research data, including large and complex data types

- gold Open Access which fosters wider collaboration and increased citations

- maximum visibility for your research: over $100 \mathrm{M}$ website views per year

At $\mathrm{BMC}$, research is always in progress.

Learn more biomedcentral.com/submissions 